\title{
Front Matter: Volume 10259
}

, "Front Matter: Volume 10259," Proc. SPIE 10259, Standards for Electronic Imaging Systems: A Critical Review, 1025901 (1 March 1991); doi:

10.1117/12.2284095

SPIE. Event: Critical Reviews, 1991, San Jose, CA, United States 


\section{Contents}

vii Preface

3 Standards for image input devices: review and forecast

D. L. Gilblom, Sierra Scientific Inc.

20 Image acquisition: quality control for document image scanners

R. Gershbock, Information International, Inc.

40 Color standards for electronic imaging

D. Q. McDowell, Eastman Kodak Co.

$54 \quad$ Preliminary review of imaging standards

V. Ren, Ramtek Corp.; D. J. Hatfield, IBM/Technical Computing

Systems; M. Deacutis, Eastman Kodak Co.

68 Evolving JPEG color data compression standard

J. L. Mitchell, IBM/Applications Solutions Div.; W. B. Pennebaker, IBM/Thomas J. Watson Research Ctr.

98 Standards for electronic imaging for graphic arts systems

S. T. Dunn, P. M. Dunn, Dunn Technology, Inc.

113 Standards for electronic imaging for facsimile systems

S. J. Urban, Delta Information Systems

146 Standards for flat panel display systems

J. C. Greeson, Jr., IBM Corp.

159 Standardization efforts for the preservation of electronic imagery

P. Z. Adelstein, Rochester Institute of Technology; W. D. Storm, Syracuse Univ.

180 Standardization of image quality measurements of medical x-ray image intensifier systems

J. M. Sandrik, General Electric Medical Systems

207 Multimedia courseware in an open-systems environment:

a DoD strategy

L. A. Welsch, National Institute of Standards and Technology

221 Imagery technology database

M. E. Courtot, Association for Information and Image Management;

M. Nier, Eastman Kodak Co.

247 Author Index

Standards for Electronic Imaging Systems: A Critical Review, edited by Michael C. Nier, Marilyn E. Courtot, Proc. of SPIE Vol. 10259 (CR37), 1025901 - ( ) (1991) 2017 SPIE · CCC code: 0277-786X/17/\$18 · doi: 10.1117/12.2284095 


\section{Preface}

The concept of standards for electronic imaging systems is hardly a new idea. Even television incorporates electronic imaging standards that date back forty and fifty years or more. However, what we are witnessing today are rapid advances in, and the integration of, technologies that have until recently been essentially separate disciplines. These changes necessitate a significant departure from the standards development process of the past, which was often the acceptance of current industry practices and other de facto standards. Today's imaging industry's requirements are anticipatory standards, which may, at times, lead the state of the art of the component technologies.

The American National Standards Institute's Image Technology Standards Board (ANSI/ITSB) has identified eight major categories for image technology standardization. These are image acquisition, recording, processing, duplication, distribution, display, evaluation, and preservation. The papers presented in this session were essentially a progress report of standards developments in these areas, as well as a sampling of the integration of these standards into certain application areas such as facsimile, medical diagnostic imaging, and the graphic arts. We hope that you will find these papers informative, thought-provoking, and a bellwether of future standards progress in electronic imaging.

As described in the program, a "Critical Review [conference] convenes a group of recognized experts, each of whom presents an ....invited paper on his or her specific field. The collection of presentations is intended to be an authoritative overview of the technology, including its developments, current status, and projections for future directions." We believe that the papers presented in the conference fulfilled this promise. Our sincere thanks to the authors for a job well done.

\section{Michael Nier}

Eastman Kodak Company

Marilyn Courtot

Association for Information and Image Management 